\title{
EFFECT OF FEEDING TWO PREDACIOUS INSECTS ON APHIDS TREATED WITH SOME ENTOMOPATHOGENS
}

\author{
IBRAHIM, A.A.; SALWA S.M. ABDEL-SAMAD and H.M. EL-SAADANY
}

Plant Protection Research Institute, ARC, Dokki, Giza, Egypt

(Manuscript received 17 April 2016)

\begin{abstract}

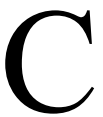
hrysoperla carnea (Stephens) and Orius albidipennis (Rueter) are a biological agents commonly used to control insect pests. Three concentrations $\left(10^{7}, 10^{8}\right.$ and $10^{9}$ spores $/ \mathrm{ml}$ ) of entomopathogenic agents Beauveria bassiana (Balsamo), Metarhizium anisopliae (Metsch) and Bacillus thuringiensis var. kurstaki (Berliner) were evaluated against the $2^{\text {nd }}$ instar larvae of $C$. carnea and $2^{\text {nd }}$ instar nymph of $O$. albidipennis. Aphids and its containers were sprayed with each concentration of spores suspension by small sprayer. The treated aphids were offers to predators as prey under laboratory conditions $\left(27 \pm 2{ }^{\circ} \mathrm{C}, 65 \pm 10 \% \mathrm{RH}\right)$. Mortality was recorded daily from the $2^{\text {nd }}$ day to the $6^{\text {th }}$ day of treatment. The results revealed that , the values of the a cumulative percentage mortalities of $C$. carnea and $O$. albidipennis increased gradually from the $2^{\text {nd }}$ day to the $6^{\text {th }}$ day after exposure and increased by increae concentrations of $B$. bassiana, and M. anisopliae. While the third agent, (Btk.) had no effect on two tested predators till the $5^{\text {th }}$ day and had slight effect on the $6^{\text {th }}$ day. The $\mathrm{LT}_{50}$ values of $C$. carnea treated with $B$. bassiana and $M$. anisopliae were 11.22 and 12.61day at concentration of $10^{7}$ spores $/ \mathrm{ml}$ and were 10.05 and 11.01 day at concentration $10^{8}$ spores $/ \mathrm{ml}$ and were 8.004 and 10.73day at concentration $10^{9}$, respectively. But not detected $L_{50}$ values for (Btk) against $C$. carnea or $O$. albidipennes at concentrations $10^{7}$, $10^{8}$ and $10^{9}$ spores $/ \mathrm{ml}$. Whereas, The $\mathrm{LT}_{50}$ values of $O$. albidipennes treated with B. bassiana and M. anisopliae were 6.3 and 5.82day at concentration $10^{7}$ spores $/ \mathrm{ml}$ and were 6.023 and 5.59day at concentration $10^{8}$ spores $/ \mathrm{ml}$ and were 3.56 and 4.32day at concentration $10^{9}$, respectively.
\end{abstract}

\section{INTRODUCTION}

Entomopathogenic fungi and bacteria have great potential control agents against insects and it considers as one component within integrated pest management systems. The entomopathogenic fungi are being developed worldwide for the control of many pests of agricultural importance (Ferron, 1985). Previous research reported that among 41 isolates of entomopathogenic fungi Beauveria bassiana and $M$. anisopliae were virulent against Myzus persicae (Sulzer) Thrips tabaci (Lindeman) (Thungrabead et al., 2006). The entomopathogenic bacteria varieties of $B$. thuringiensis which is based on Cry toxins (also known as $\delta$ - endotoxins) are now 
commercially available for use against a wide variety of insect pests including species of Lepidoptera, Coleoptera and Diptera (Gill et al., 1992).

However, the success of entomopathogens as biological control agents depends not only on high efficacy against insect pests, but also on low or no effect against non-target insects. Moreover, use of such biological control agents might have effect on beneficial insects, such as natural enemies of insect pests (Ahmadzadeh \& Hatami1, 2006).

Larvae of $C$. carnea are efficient predator as bio control tool predators against many key pests including aphids, whiteflies, young larvae and eggs of Lepidoptera, spider mites and other soft bodied arthropods (Cardoso and Lazzari, 2003). It can be mass reared in the laboratory and released against pests in field and greenhouses (Mirnoayedi, 2001).

Species in the genus Orius (Hemiptera: Anthocoridae) are generalist predators that attack eggs and immature stages of various arthropods, or small soft-bodied adult arthropods, including numerous important agricultural pest species (Butler and O'Neil 2007). Although, Orius spp. are polyphagous and show a preference for attacking larval and adult thrips (Thysanoptera) over other available prey ( $\mathrm{Xu}$ and Enkegaard 2009). Consequently, they are considered promising and effective as biological control agents and have been used successfully in biological control programs in greenhouse and open-field cropping systems against various thysanopteran pests.

The present work aimed to study the effect of entomopathogenic agents $B$. bassiana, M. anisopliae and (Btk) on C. carnea and $O$. albidipennis in the laboratory to clarify the possibility of the introduction of these elements together in integrated pest management systems and the interaction between them.

\section{MATERIALS AND METHODS}

\section{A-Culture of $B$. bassiana and $M$. anisopliae :}

Two entomopathogenic fungi, B. bassiana and M. anisopliae were isolated in Bio- insecticide Production Unit, Plant Protection Research Institute-Agriculture Research Center. The first fungus was isolated from the white fly in the Sharkia Governorate and the second fungus was isolated from the red palm weevil in Ismailia Governorate. (Ibrahim, 2006).

Fungal cultures of $B$. bassiana and $M$. anisopliae were grown at $25 \pm 2{ }^{\circ} \mathrm{C}$, in dark, on Sabouraud dextrose agar (SDA), consisted of peptone $10 \mathrm{~g} / \mathrm{L}$, glucose 20 $\mathrm{g} / \mathrm{L}$, and agar-agar $20 \mathrm{~g} / \mathrm{L}$. Spores were harvested from 15 days old plates by scraping 
into sterile $0.05 \%$ Tween 80 . The suspension was vortexed for 2 min. Dilutions were prepared to give range of concentrations $10^{7}, 10^{8}$ and $10^{9} \mathrm{spores} / \mathrm{ml}$.

\section{B- Culture of Bacillus thuringiensis :}

Bacillus thuringiensis subspecies kurstaki (Btk) was isolated in Bio- insecticide Production Unit, Plant Protection Research Institute.

Culture of Btk were carried out according to Attathom et al. (1995) as follows: T3 medium was prepared which composed of tryptone $3.0 \mathrm{~g}$, tryptose $2.0 \mathrm{~g}$, yeast extract $1.5 \mathrm{~g}, \mathrm{MnCl}_{2} 0.005 \mathrm{~g}$ and $\mathrm{NaH}_{2} \mathrm{PO}_{4} . \mathrm{H}_{2} \mathrm{O} 8.9 \mathrm{~g}$, adjusted $\mathrm{pH}$ to 6.8 and the final volume was made up to 1 liter with distilled water. The sterilized medium was inoculated and incubated on a shaker $(142 \mathrm{rpm})$ at $28^{\circ} \mathrm{C}$ for $72 \mathrm{hr}$.

The number of $\mathrm{CFU} / \mathrm{ml}$ of the suspension, which resulted from the previously technique of production, was determined by plate count method, Concentrations of spores suspension were prepared $\left(107,10^{8}\right.$ and $10^{9}$ spores $\left./ \mathrm{ml}\right)$.

\section{C-Rearing technique of Chrysoperla carnea and Orius albidipennis:}

Stock of $C$. carnea larvae and Orius albidipennis nymph were obtained from "Aphid lion, Chrysopa mass rearing unit" at the faculty of Agriculture, Cairo University, Egypt.

\section{D-Rearing of Aphis craccivora}

Rearing of cowpea aphid $A$. craccivora was carried out according to the technique described by Abdel-Samad (1996). Pure culture of the aphid was maintained in the laboratory for this study.

\section{E-Bioassay :}

Spores suspension of B. bassiana, M. anisopliae and (Btk) were prepared in sterile $0.05 \%$ Tween 80 water solution. The mortality effects of the entomopathogenic fungi and bacteria on two insect predators, C. carnea and $O$. albidipennis were performed by testing three concentrations of spores suspension from each agent $\left(1 \times 10^{7}, 1 \times 10^{8}\right.$ and $1 \times 10^{9}$ spores $\left./ \mathrm{ml}\right)$.

Cowpea aphids were transferred into the plastic containers ( $12 \mathrm{~cm}$ diameter and $23 \mathrm{~cm}$ height). The containers and aphids were sprayed with each concentration of agent and distilled water as control. The experiment was replicated 3 times. Each replicate was provided with ten $2^{\text {nd }}$ instar larvae of $C$. Carnea and ten $2^{\text {nd }}$ nymph of $O$. albidipennis, then were covered with muslin cloth for aeration. The containers were maintained in an incubator at $25 \pm 2,60-70 \% \mathrm{RH}$. Dead larvae and nymphs were counted daily and mortality was calculated. Also, the median lethal time $\left(\mathrm{LT}_{50}\right)$ of mortality was calculated. 


\section{F-Statistical Analysis}

The mortality percentage reduction of larvae and nymphs was calculated and corrected according to Abbott's formula (1925). For determination of the lethal times $\mathrm{LT}_{50}$, according to Finney (1971), data were analyzed using Ldp line software developed by Dr. Ehab Bakr, Plant Protection Research Institute http://www.Ehabsoft.com.

\section{RESULTS AND DISCUSSION}

The effects of three entomopathogenic agents B. bassiana, M. anisopliae and B. thuringiensis were evaluated at three concentrations $\left(10^{7}, 10^{8}\right.$ and $\left.10^{9}\right)$ spores $/ \mathrm{ml}$ against the $2^{\text {nd }}$ instar larvae of $C$. carnea and $2^{\text {nd }}$ instar nymph of $O$. albidipennis. Suspension were sprayed by small sprayer on aphids ( $A$. craccivora ), the aphids were offers to predators as prey under laboratory conditions at $27 \pm 2{ }^{\circ} \mathrm{C}, 65 \pm 10 \%$ $\mathrm{RH}$ and $16 \mathrm{~h}$ photophase. Mortality was recorded daily from the $2^{\text {nd }}$ day till the $6^{\text {th }}$ day of treatment.

Data in Table (1) showed cumulative mortalities of the second instar larvae of C. carnea fed on aphids treated with B. bassiana, M. anisopliae and B. thuringiensis. The results revealed that the values of the cumulative mortalities increased gradually from the $2^{\text {nd }}$ day after exposure until the $6^{\text {th }}$ day. Also, as concentration increased for $B$. bassiana, M. anisopliae. While the third agent, $B$. thuringiensis had no effect on $C$. carnea until the $5^{\text {th }}$ day but had a slight effect at the $6^{\text {th }}$ day.

The effect of pathogen, $B$. bassiana was evident by the $2^{\text {nd }}$ day of treatment in the three concentrations $\left(10^{7}, 10^{8}\right.$ and $\left.10^{9}\right)$ spores $/ \mathrm{ml}$ with recorded mortality $(0$, 7.95 and 12.44) respectively. However, mortality percentages of $C$. carnea larvae treated with $B$. bassiana at $6^{\text {th }}$ day post treatment reached $18.92 \%$ at the concentration $10^{7}$ spores $/ \mathrm{ml}$ and increased to $40.53 \%$ at the highest concentration i.e. $10^{9} \mathrm{spores} / \mathrm{ml}$.

Also, Cumulative percent mortality of $C$. carnea larvae fed in the second instar with aphids treated with $M$. anisopliae illustrated in Table (1). The results showed that the cumulative percent mortalities were $1.71,1.52$ and $2.32 \%$ at the second day post treatment and increased to reach $19.47,21.84$ and $24.47 \%$ at the $6^{\text {th }}$ day after treatment for concentrations $\left(10^{7}, 10^{8}\right.$ and $\left.10^{9}\right)$ spores $/ \mathrm{ml}$ respectively. While the respective values of mortality percentages of $C$. carnea larvae fed in the second instar with aphids treated with (Btk) were zero at $2^{\text {nd }}, 3^{\text {rd }}, 4^{\text {th }}$ and $5^{\text {th }}$ day after treatment for all concentrations and reached to $4.70 \%, 6.80 \%$ and $6.80 \%$ at the $6^{\text {th }}$ day for concentrations of $10^{7}, 10^{8}$ and $10^{9}$ spores/ ml, respectively. 
Cumulative percent mortalities of $O$. albidipennes nymphs contaminated with B. bassiana, M. anisopliae and fed in the second instar on aphids treated with (Btk) are show in Table (2).The results confirmed that the values of the cumulative mortalities increased gradually from the $2^{\text {nd }}$ day after exposure until the $6^{\text {th }}$ day and increased with increasing concentrations of $B$. bassiana and $M$. anisopliae, while the third agent, $B$. thuringiensis had no effect on predator, $O$. albidipennes until the $6^{\text {th }}$ day. Mortality percentage at the second day 0 , and11.60 with concentrations $10^{7}, 10^{8}$ spores $/ \mathrm{ml}$ respectively, and $28.46 \%$ at concentration $10^{9} \mathrm{spores} / \mathrm{ml}$ for treated with $B$. bassiana. However, mortality percentages of $O$. albidipennes nymphs treated with $B$. bassiana at $6^{\text {th }}$ day post treatment reached $47.14 \%$ at the concentration of $10^{7}$ spores $/ \mathrm{ml}$ and increased to $69.64 \%$ at the highest concentration i.e. $10^{9} \mathrm{spores} / \mathrm{ml}$.

. As for the fungus M. anisopliae, mortality percentages in 0 . albidipennes nymphs at $2^{\text {nd }}$ day post treatment were $0,14.66$ and $21.50 \%$ at the concentrations $\left(10^{7}, 10^{8}\right.$ and $10^{9}$ spores/ $\left.\mathrm{ml}\right)$ respectively, and increased at $6^{\text {th }}$ day after treatment to reach $55.01,52.86$ and $63.10 \%$ at concentrations $\left(10^{7}, 10^{8}\right.$ and $10^{9}$ spores/ ml) respectively. Where the respective values of mortality percentages of 0 . albidipennes nymphs fed in the second instar with aphids treated with $B$. thuringiensis were zero at $2^{\text {nd }}, 3^{\text {rd }}, 4^{\text {th }}$ and $5^{\text {th }}$ day after treatment for all concentrations and reached to $6.5,8.49$ and 8.49 at the $6^{\text {th }}$ day for concentrations $\left(10^{7} 10^{8}\right.$ and $10^{9}$ spores/ $\left.\mathrm{ml}\right)$ respectively.

Table 1. A Cumulative percent mortality of $C$. carnea larvae treated with $B$. bassiana, $M$. anisopliae and fed in the second instar on aphids treated with $B$. thuringiensis var. kurstaki.

\begin{tabular}{|c|c|c|c|c|c|c|}
\hline \multirow{2}{*}{ Entomopathogenic agents } & \multirow{3}{*}{ Con.(spores/ml) } & \multicolumn{5}{|c|}{ Corrected mortality (\%) } \\
\hline & & \multicolumn{5}{|c|}{ Days } \\
\hline \multirow{4}{*}{ Beauveria bassiana } & & 2 & 3 & 4 & 5 & 6 \\
\hline & $1 \times 10^{7}$ & 0 & 2.85 & 6.8 & 12.14 & 18.29 \\
\hline & $1 \times 10^{8}$ & 7.95 & 14.58 & 21.08 & 27.13 & 32.64 \\
\hline & $1 \times 10^{9}$ & 12.44 & 20.71 & 28.2 & 34.77 & 40.53 \\
\hline \multirow{3}{*}{ Metarhizium anisopliae } & $1 \times 10^{7}$ & 1.71 & 4.82 & 9.17 & 14.19 & 19.47 \\
\hline & $1 \times 10^{8}$ & 1.52 & 4.81 & 9.74 & 15.60 & 21.84 \\
\hline & $1 \times 10^{9}$ & 2.32 & 6.49 & 12.03 & 18.19 & 24.47 \\
\hline \multirow{3}{*}{ Bacillus thuringiensis } & $1 \times 10^{7}$ & 0 & 0 & 0 & 0 & 4.70 \\
\hline & $1 \times 10^{8}$ & 0 & 0 & 0 & 0 & 6.80 \\
\hline & $1 \times 10^{9}$ & 0 & 0 & 0 & 0 & 6.80 \\
\hline
\end{tabular}


Table 2. A Cumulative percent mortality of $O$. albidipennes nymphs treated with $B$. bassiana, $M$. anisopliae and fed in the second instar on aphids treated with B. thuringiensis

\begin{tabular}{|c|c|c|c|c|c|c|}
\hline \multirow{3}{*}{ Entomopathogenic agents } & \multirow{3}{*}{ Con.(spores/ml) } & \multicolumn{5}{|c|}{ Corrected mortality (\%) } \\
\hline & & \multicolumn{5}{|c|}{ Days } \\
\hline & & 2 & 3 & 4 & 5 & 6 \\
\hline \multirow{3}{*}{ Beauveria bassiana } & $1 \times 10^{7}$ & 0 & 14.01 & 25.42 & 36.81 & 47.14 \\
\hline & $1 \times 10^{8}$ & 11.60 & 22.49 & 32.86 & 42.00 & 49.84 \\
\hline & $1 \times 10^{9}$ & 28.46 & 43.27 & 54.55 & 63.09 & 69.64 \\
\hline \multirow{3}{*}{ Metarhizium anisopliae } & $1 \times 10^{7}$ & 0 & 0.37 & 6.49 & 27.01 & 55.01 \\
\hline & $1 \times 10^{8}$ & 14.66 & 26.21 & 36.59 & 45.43 & 52.86 \\
\hline & $1 \times 10^{9}$ & 21.50 & 35.40 & 46.81 & 55.88 & 63.10 \\
\hline \multirow{3}{*}{ Bacillus thuringiensis } & $1 \times 10^{7}$ & 0 & 0 & 0 & 0 & 6.50 \\
\hline & $1 \times 10^{8}$ & 0 & 0 & 0 & 0 & 8.49 \\
\hline & $1 \times 10^{9}$ & 0 & 0 & 0 & 0 & 8.49 \\
\hline
\end{tabular}

Table 3. Median Lethal Time of $C$. carnea and $O$. albidipennes after treated with $B$. bassiana, M. anisopliae and (BtK)..

\begin{tabular}{|c|c|c|c|c|c|c|}
\hline \multirow{2}{*}{ Entomopathogenic agents } & \multicolumn{6}{|c|}{ Median Lethal Time (Days) } \\
\cline { 2 - 7 } & \multicolumn{3}{|c|}{ C. carnea } & \multicolumn{3}{c|}{ O. albidipennes } \\
\cline { 2 - 7 } & $1 \times 10^{7}$ & $1 \times 10^{8}$ & $1 \times 10^{9}$ & $1 \times 10^{7}$ & $1 \times 10^{8}$ & $1 \times 10^{9}$ \\
\hline B.bassiana & 11.22 & 10.05 & 8.00 & 6.30 & 6.02 & 3.56 \\
\hline M. anisopliae & 12.61 & 11.01 & 10.73 & 5.82 & 5.59 & 4.32 \\
\hline B. thuringiensis & \multicolumn{6}{|c|}{ Not detect } \\
\hline
\end{tabular}

The $\mathrm{LT}_{50}$ values of $C$. carnea larvae of $C$. carnea treated with $B$. bassiana in Table (3) were 11.22 days, 10.05 days and8.00 days at concentrations of $10^{7}, 10^{8}$ and $10^{9}$ spores $/ \mathrm{ml}$, respectively. They were 12.61 days, 11.01 days and 10.73 days at concentrations of $10^{7}, 10^{8}$ and $10^{9}$ spores $/ \mathrm{ml}$, respectively for treated with $M$. anisopliae. Whereas, the $\mathrm{LT}_{50}$ values of $O$. albidipennes nymphs treated with $B$. bassiana and $M$. anisopliae were 6.30 days and 5.82 days at concentration of $10^{7}$ spores $/ \mathrm{ml}$, respectively. $\mathrm{LT}_{50}$ values were 3.56 days and 4.32 days at concentration of $10^{9}$ spores $/ \mathrm{ml}$ with $B$. bassiana and $M$. anisopliae, respectively But, $\mathrm{LT}_{50}$ values had not detected for (Btk) against $C$. carnea or $O$. albidipennes at all concentrations.

Our results indicate that beneficial organisms are susceptible to infection by B.bassiana and $M$. anisopliae by means of both direct and indirect exposure to entomopathogenic fungi under laboratory. The results reveal that different genera or species of fungi had different pathogenicity and virulence. Entomopathogenic fungus could be quite specific and might infect only certain type of host. These results were 
supported by Magalhães et al. (1988). Who noted that $B$. bassiana caused mycosis in $60 \%$ of adult Coleomegilla maculata lengi Timberlake (Col., Coccinellidae) and in 35\% of adult Eriopis connexa (Col., Coccinellidae), when conidia were applied directly to the insects. Todorova and colleagues (1994) remarked that different strains of $B$. bassiana showed different efficacies on larvae of $C$. maculata lengi. The different ecological host ranges of different entomopathogenic fungus isolates, e.g. coevolution between hosts and pathogens could partially explain the different susceptibilities found in this study and in previously report. That in agreement to demonstration of James and Lighthart (1994) mentioned that, B. bassiana and $M$. anisopliae caused up to $97 \%$ and $95 \%$ mortality, respectively, to $1^{\text {st }}$ instars larvae of the Coccinellid, Hippodamia convergens, a common predator of aphids. Scott and Ronald (2001) evaluated the direct and indirect effect of a commercial formulation of Beauveria bassiana strain JW-1 against Orius insidiosus (Say), Phytoseiulus persimilis Athias-Henriot, Encarsia formosa Gahan, and Aphidius colemani Viereck were under greenhouse cage and laboratory conditions. They found that the natural enemies were highly susceptible to infection under laboratory conditions, and lower infection rates were observed in the greenhouse trials. It is common for entomopathogenic fungi to infect hosts in laboratory which are never infected in the field (Butt and Goettel, 2000). Furthermore, insect species may be easily infected in laboratory by fungi which are not known to attack them in nature. Also there are different terms between the natural hosts from which the pathogen has been isolated, under laboratory conditions ( Hajek and Goettel, 2000).

The experiment in which first instars were treated revealed no negative effects on development time or survivorship of immature $O$. sauteri, or on their longevity as adults, regardless of the concentrations of $B$. assiana formulation used (Gao et al. 2012). In contrast, Thungrabeab and S. Tongma (2007) showed that $B$. bassiana was found to be non-pathogenic to $C$. carnea and Dicyphus tamaninii and beneficial soil insect with highest fungal concentration $\left(10^{8}\right.$ conidia/ml), while $M$. anisopliae had pathogenicity to natural enemies, $C$. carnea and D. tamaninii. Our study revealed also that no significant differences in mortality occurred when $C$. carnea and $O$. albidipennes larvae were treated with $\mathrm{Bt}$ and untreated aphids. These results agree with Al-Deeb et al. (2001), they suggested that Bt corn and B. thuringiensis subsp. kurstaki had no significant effect on the predator $O$. insidiosus. Varieties of Bt., the insecticidal activity of which is based on Cry toxins (also known as $\delta$-endotoxins), are now commercially available for use against a wide variety of insect 
pests including species of Lepidoptera, Coleoptera and Diptera. The individual Cry toxins are for the most part active against single orders of insect pests and may affect one to several families within an order. The specificity of toxins is determined by the molecular configuration of the toxin and the physiology of the host midgut and presence of toxin receptors on the midgut epithelium (Gill et al. 1992).

\section{CONCLUSIONS}

We can conclude that both isolates of $B$. bassiana, and M. anisopliae are not recommended to be applied at the same time with predators $C$. carnea and $O$. albidipennes as bio control agent in an IPM programs. This isolates of B. bassiana, M. anisopliae could be used for rabid, short-term suppression and C. carnea and $O$. albidipennes could be used for longer-term suppression of pest. While, we can suggest that use of $B$. thuringiensis var. kurstaki can be compatible with $C$. carnea and $O$. albidipennes or other insect predators, which is an important component of an IPM system.

\section{REFERENCES}

1. Abbott, W.S. 1925. A method for computing the effectiveness of an insecticide. J. Econ. Entomol. 18: 265- 277

2. Abdel-Samad, S. M. Salwa. 1996. Studies on natural enemies of certain insects attacking leguminous crops. M.Sc. Faculty of Agric. Ain Shams Univ. 1-94.

3. Ahmadzadeh, Z. and B. Hatami. 2006. Evaluation of Integrated Control of Greenhouse Whitefly, Trialeurodes vaporariorum West. Using Chrysoperla carnea (Steph.) and Insecticide Confidor in Greenhouse Conditions. J. Sci. \& Technol. Agric. \& Natur. Resour., 9 (4) : 239-251.

4. Al-Deeb, M. A.; G. E. Wilde and R. A. Higgins. 2001. No Effect of Bacillus thuringiensis Corn and Bacillus thuringiensis on the Predator Orius insidiosus (Hemiptera: Anthocoridae). Environ. Entomol. 30(3):625-629.

5. Attathom, T.; W. Chongrattanameteekul; J. Chanpaisang and R. Siriyan. 1995. Morphological diversity and toxicity of delta-endotoxin produced by various strains of Bacillus thuringiensis. B. Entomol. Res. 85: 167-173.

6. Butler, C. D. and R. J. O'Neil. 2007. Life history characteristics of Orius insidiosus (Say) fed Aphis glycines Matsumura. Biol. Control 40:333-338. 
7. Butt, T. M. and M. S. Goettel. 2000. Bioassays of entomogenous fungi. Pp. 141195. In: Bioassays of entomopathogenic microbes and nematodes, A. Navon and K. R. S. Ascher (eds). (CAB international, UK).

8. Cardoso, J. T. and S. N. Lazzari. 2003. Development and consumption capacity of Chrysoperla externa (Hagen) (Neuroptera, Chrysopidae) fed with Cinara spp. (Hemiptera, Aphididae) under three temprerture. (revista Brasileira de Zoologia, 20 (4): 573-576.

9. Finney,D.J. 1971. Probit Analysis, A statistical Treatment of the Sigmoid Response Curve, $6^{\text {th }}$ Ed ., Cambridge Univ.Press, Cambridge,England.

10. Ferron, P. 1985 Fungal Control. In: Kerkut, G. A. and Gilbert, L. I., Eds. Comparative Insect physiology, Biochemistry and Pharmacology. Oxford, Pergamon Press, pp. 313-346.

11. Gao, Y.; S. R. Reitz; J. Wang; P. Tamez-Guerrac; E. Wanga; X. Xua and Z. Lei. 2012. Potential use of the fungus Beauveria bassiana against the western flower thrips Frankliniella occidentalis without reducing the effectiveness of its natural predator Orius sauteri (Hemiptera: Anthocoridae). Biocontrol Scien. Technol., 22 (7) :803-812.

12. Gill, S.S.; E.A. Cowles and P.V. Pietrantonio. 1992. The mode of action of Bacillus thuringiensis endotoxins. Annu. Rev. Entomol. 37:615-636.

13. Hajek, A. E. and M. S. Goettel. 2000. Guidelines for evaluating effects of entomopatogens on non-target organisms. PP. 847- 968 (In: Field Manual of Technique in Invertebrate Pathology L.A. Lary and H. K. Kaya (eds.), Klluer Academic Publishers, Netherland).

14. Ibrahim, A. A. 2006. Action of certain microbes on cotton leaf worm. Ph.D. Thesis, Faculty Scie., Al-Azhar Univ., 171pp.

15. James, R. R. and B. Lighthart. 1994. Susceptibility of the convergent lady bettle (Coleoptera: Coccinellidae) to four Entomogenous fungi. Entomgenous Fungi and Hippodamia 23 (1): 190-192.

16. Magalhães, B.P.; J. C. Lord; S. P. Wraight; R.A. Daoust and D.W. Roberts. 1988. Pathogenicity of Beauveria bassiana and Zoophthor aradicans to The Coccinellid Predators Coleomegilla maculata and Eriopsis connexa, J. Invert. Pathol., 52: 471-473.

17. Mirnonoayedi, A. 2001. The effect of experimental release of eggs and larvae of Chrysoperla carnea insecta, Neuroptera, Chrysopidae on the reduction of attack 
of Earias insulana, on cotton bolls, in Kermanshah, Iran. (Abst.) (The first conference on Integrated Pest Management 22-23 April, 2001, Cairo).

18. Scott, W. L. and D. O. Ronald. 2001. Susceptibility of Natural Enemies to Infection by Beauveria bassiana and Impact of Insecticides on Ipheseius degenerans (Acari: Phytoseiidae). J. Agric. Urban Entomol. ,18 ( 3):169-178

19. Thungrabeab, M.; P. Blaeser and C. Sengonca. 2006. Effect of Temperature and Host Plant on Efficacy of Different Entomopathogenic Fungi from Thailand Used against Frankliniella occidentalis (Pergande) (Thys., Thripidae) and Thrips tabaci lindeman (thys., Thripidae) in the Laboratory. J. Plant diseas. Protec., 113(4):181-187.

20. Thungrabeab, M. and S. Tongma. 2007. Effect of Entomopathogenic Fungi, Beauveria bassiana (Balsam) and Metarhizium anisopliae (Metsch) on Non Target Insects. KMITL Sci. Tech. J. , 7 ( S1):8-12.

21. Todorova, S.I.; J. C. Cote; P. Martel and D. Coderre. 1994. Heterogenecity of Two Beauveria bassiana Strains Revealed by Biochemical Tests, Protein Profiles and Bioassays on Leptinotarsa decemlineata (Col., Chrysomelidae) and Leomegilla maculata lengi (Col., Coccinellidae) Larvae. Entomophaga, 39 :159169.

22. Xu, X. and A. Enkegaard. 2009. Prey preference of Orius sauteri between Western Flower Thrips and spider mites. Entomol. Exp. Appl., 132:93-98. 


\title{
تأثير تفذية مفترسين حشريين على المن المعامل ببعض الممرضات الحشرية
}

\author{
أحمد عدلى ابراهيم ، سلوى سيا محمد عبد الصمد ، حسن محمد السعدنى \\ معهُ بحوث وقاية النباتات - مركز البحوث الزراعية - الدقى - الجيزة - مصر
}

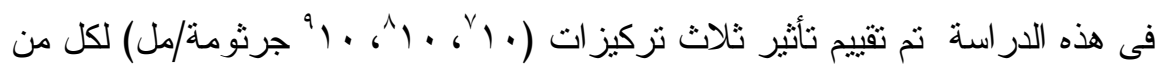

Metarhizium geauveria bassiana , Bacillus thuringiensis var. kurstaki (Btk), anisopliae لحوريات مفترس بقة الأوريس Orius albidipennis. نم رش من الفول بالتركيزات السابقة ثم تقديمه لكلاً المفترسين تحت ظروف المعدل. ونم منابعة وأخذ النتائج من اليوم الثانى حتى اليوم

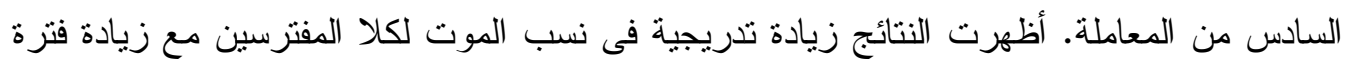

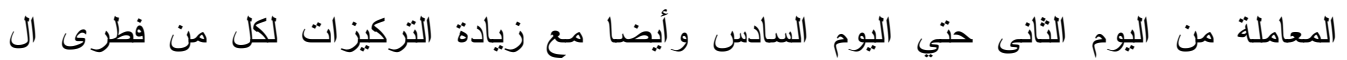
Betarhizium anisopliae و . بينما لم تظهر بكتريا Btk أى تأثير حتى اليوم الخامس من المعاملة مع ظهور تأثثر ضعيف جدا فى اليوم السادس لكل التركيزات مع كلا

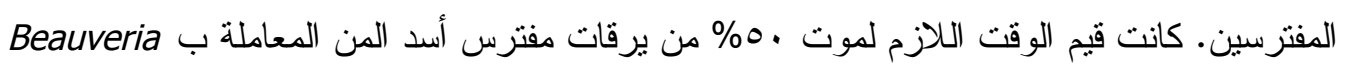
Metarhizium anisopliae و هى r. bassiana

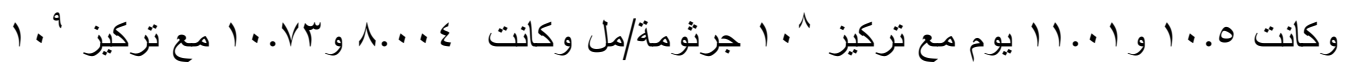

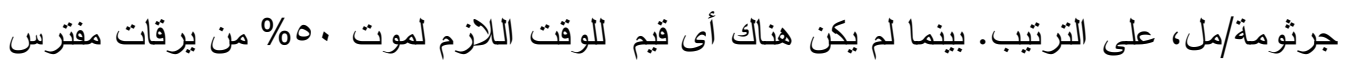

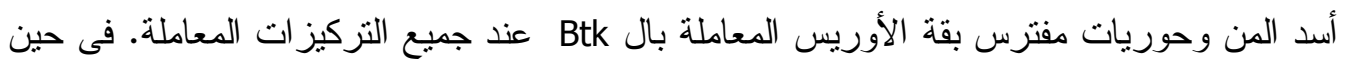

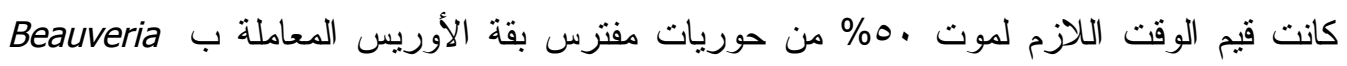
Metarhizium anisopliae و هى س.7 bassiana

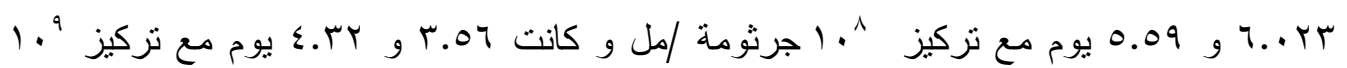
جرثومة/مل، على الترتيب. 